\author{
А. В. Бойчук \\ ORCID https://orcid.org/0000-0002-2191-0383 \\ ResearcherID W-1870-2017 \\ Scopus Author ID 57219835870 \\ В. С. Шадріна \\ ORCID https://orcid.org/0000-0003-3731-4700 \\ О. І. Хлібовська \\ ORCID https://orcid.org/0000-0003-3293-0010
}

Тернопільський національний медичний університет імені І. Я. Горбачевського МОЗ Украӥни

\title{
ОСОБЛИВОСТІ НАВЧАЛЬНОГО ПРОЦЕСУ НА КАФЕДРІ АКУШЕРСТВА ТА ГІНЕКОЛОГІЇ ПІСЛЯДИПЛОМНОЇ ОСВІТИ В КОНТЕКСТІ ІНТЕГРАЦІЇ ДО ЄВРОПЕЙСЬКОГО ОСВІТНЬОГО ПРОСТОРУ
}

\author{
A. V. Boychuk, V. S. Shadrina, O. I. Khlibovska \\ I. Horbachevsky Ternopil National Medical University \\ PECULIARITIES OF THE EDUCATIONAL PROCESS AT THE \\ DEPARTMENT OF OBSTETRICS AND GYNECOLOGY OF \\ POSTGRADUATE EDUCATION IN THE CONTEXT OF INTEGRATION \\ INTO EUROPEAN EDUCATION
}

\begin{abstract}
Анотація. Завдяки використанню IT-технологій для дистанційного (у тому числі в режимі on-line) навчання є можливість для лікарів акушерів-гінекологів бути ознайомленими з не тільки відпрацьованими методиками, схемами, підходами в лікувальному процесі, а й з новинками в цій сфері, підвищувати професійну кваліфікацію без припинення робочого процесу. Для формування системи професійних теоретичних та практичних знань у лікарів-інтернів та лікарів-курсантів у світі широко застосовують ситуаційне моделювання.

Використання у навчальному процесі ситуаційних задач сприяє активності лікарів-інтернів та курсантів у практичній роботі, їх професійному розвитку та дисциплінації мислення.
\end{abstract}

Ключові слова: IT-технології; дистанційне навчання; професійний ріст; симуляційне навчання; ситуаційні задачі.

Abstract. Due to the use of IT technologies for distance learning (including on-line training), it is possible for doctors obstetriciangynecologists to be acquainted with not only worked out techniques, schemes, approaches in the medical process, but also with novelties in this area, to increase professional qualifications without termination of the work process. For the formation of a system of professional theoretical and practical knowledge among interns and doctors-cadets in the world, situational modeling is widely used.

The use of situational tasks in the educational process promotes the activity of interns and students in practical work, their professional development and discipline of thinking.

Key words: IT technologies; distance learning; professional growth; simulation training; situational tasks.

Вступ. Стратегічні напрями реорганізації вітчизняної системи вищої медичної та фармацевтичної освіти визначаються як внутрішньодержавними процесами, так і тенденціями загальносвітового розвитку, а відтак передбачають приведення іï структури, змісту та якості у відповідність до потреб та вимог системи охорони здоров'я і до міжнародних стандартів.

(C) А. В. Бойчук, В. С. Шадріна, О. І. Хлібовська
Вища медична освіта повинна забезпечити високоякісну підготовку студентів і $є$ важливою складовою реформування галузі охорони здоров'я та реалізації соціальних пріоритетів держави, оскільки від рівня підготовки майбутніх лікарів залежить якість надання медичної допомоги населенню країни. Сучасний розвиток медичної науки і практики зумовлює необхідність вносити корективи в підготовку та підвищення кваліфікації ме- 
дичних працівників із наближенням їх освіти до міжнародних стандартів. Саме тому якість освіти в закладах вищої освіти необхідно покращити шляхом ефективної організації та інформатизації навчального процесу, впровадженням передових наукових розробок у практику викладання, забезпеченням високого професіоналізму викладачів, створенням сучасної навчально-методичної бази в усіх освітніх галузях, зокрема і медичній.

Мета статті - оцінити особливості викладання теоретичних та практичних знань лікарям-інтернам та лікарям-курсантам зі спеціальності «Акушерство та гінекологія», ефективність оволодіння ними спеціальними навичками в практичній роботі лікаря.

Теоретична частина. Освіта належить до найважливіших напрямків державної політики України. Держава виходить з того, що освіта - це стратегічний ресурс соціально-економічного, культурного й духовного розвитку суспільства, поліпшення добробуту людей, забезпечення національних інтересів, зміцнення міжнародного авторитету і формування позитивного іміджу нашої держави, створення умов для самореалізації кожної особистості. 3 огляду на визначені пріоритети найважливішим для держави є виховання людини інноваційного типу мислення та культури з урахуванням інноваційного розвитку освіти, запитів особистості, потреб суспільства та держави. Якісна освіта $є$ необхідною умовою забезпечення сталого демократичного розвитку суспільства, формування нових життєвих орієнтирів особистості. У контексті обраного курсу європейської інтеграції України освіта покликана подолати протиріччя між потребами розвитку України та пережитками тоталітарної епохи, освіта повинна відповідати новим політичним та економічним реаліям, допомогти молодому поколінню увійти у світовий інформаційний простір. Інтеграція в європейське освітнє середовище потребує також підвищення рівня володіння іноземними мовами. У процесі реформування вищої освіти необхідно використовувати європейський досвід, залучати до обговорення громадськість, підтримувати конкурентність 3 метою активізації ринкових механізмів забезпечення якості освітніх послуг. Процес євроінтеграції передбачає створення загальноєвропейського освітнього та наукового простору на основі розроблення єдиних критеріїв і стандартів у галузі освіти та науки 3 метою визнання періодів і термінів підготовки фахівців з вищою освітою, що сприятиме спів- робітництву між вищими навчальними закладами Європи [1, 6, 7].

Сучасна медична освіта $є$ процесом безперервного навчання, що включає оновлення й у сфері вищої медичної освіти. Окрім того, далеко не всі запропоновані сьогодні методики активного навчання мають достатнє психолого-педагогічне обгрунтування, однак багато з них успішно застосовуються у викладацькій діяльності $[7,8]$.

Основним напрямком удосконалення процесу підвищення кваліфікації лікарів акушерів-гінекологів на етапі післядипломної освіти є поступове впровадження сучасних форм навчання. Інтернатура - перший крок до самостійної роботи лікаря, тому важливо, починаючи саме з цього етапу, направляти зусилля молодого спеціаліста до самовдосконалення. Традиційні методи навчання лікарів-інтернів, у першу чергу, направлені на набуття і використання знань шляхом передачі інформації з наступним її впровадженням у конкретних професійних діях згідно з готовим алгоритмом. Такий підхід на сьогодні при підготовці лікарів працює в зв’язку з переходом практичної охорони здоров’я на надання медичної допомоги жінкам відповідно до протоколів МОЗ України [13, 14].

Для реалізації організаційних умов і методологічних підходів, які сприяють підвищенню ефективності навчання лікарів-інтернів та лікарів-курсантів, необхідно виділити ряд завдань [5, 6, 9].

Перш за все, необхідно визначити суть, зміст і структуру дистанційного навчання. Потім необхідно окреслити організаційні умови та методологічні підходи, які сприяють його розвитку на етапі післядипломної освіти [2, 3, 14].

Дистанційне навчання при підготовці лікарівінтернів, лікарів-курсантів - це інноваційна організація навчального процесу, яка реалізується в специфічній педагогічній системі, яка базується на принципі самостійного навчання лікаря й інтерактивної взаємодії викладача та інтерна або курсанта [2, 3].

Результативність дистанційного навчання на післядипломному етапі освіти лікарів акушерівгінекологів значною мірою залежить від таких факторів: ефективної взаємодії викладача і лікаря; відлагодженого активного зворотного зв'язку; в якості попереднього проектування процесу дистанційної освіти та способів керування ним; розробки дидактичних матеріалів. Сучасні комп’ютерні програми дозволяють забезпечити передачу знань і доступ до різнобічної навчальної інформації; 
а нові технології, такі як інтерактивні електронні навчальні посібники, мультимедійне забезпечення, мережа «Інтернет», сприяють більш активному долученню лікарів до процесу навчання. Інтерактивні можливості систем доставки інформації дозволяють відлагодити і навіть стимулювати зворотний зв’язок, забезпечити діалог та постійну підтримку, які неможливі в більшості традиційних систем навчання [10, 11, 12].

Згідно з робочою програмою зі спеціальності «Акушерство та гінекологія», яка затверджена МОН України, лікарі-інтерни мають години для самостійної позааудиторної підготовки. Але на сьогодні ця підготовка використовується з низьким коефіцієнтом ефективності. Вирішити цю проблему можна деякими шляхами. Насамперед, це підвищення мотивації молодого спеціаліста до самостійної роботи. Можливим варіантом підготовки лікаря-інтерна до заняття може бути створення мультимедійної презентації з потрібної теми з використанням можливостей сучасного програмного забезпечення та мережі «Інтернет» [13].

Важливим у такому методі підготовки до практичних занять $є$ формування навичок самостійної роботи та стимулювання творчого підходу до навчання. По-друге, це створення на базі кафедри комп’ютерних класів, які мають бути забезпечені електронними навчальними та методичними матеріалами: навчальними посібниками, розробленими працівниками кафедри; мультимедійними презентаціями до занять згідно з тематичним планом; фото- та відеоматеріалами; тестовими завданнями як навчального, так і контролюючого типу [4, 7, 8].

Основним завданням вищої школи є підвищення якості підготовки спеціалістів.

Підготовка лікарів включає формування системи професійних теоретичних знань, практичних навичок, умінь для вирішення будь-яких професійних, часом складних, нестандартних завдань.

Для формування системи професійних теоретичних та практичних знань у лікарів-інтернів та лікарів-курсантів у світі широко застосовують ситуаційне моделювання.

Використання у навчальному процесі ситуаційних задач сприяє активності інтернів у практичній роботі, їх професійному розвитку та дисциплінує мислення.

Найбільш визначним є проблемний метод викладання, що передбачає створення ситуаційних задач різного рівня складності $[4,7,8]$.
Створений у нашому університеті симуляційний центр дозволяє нашим лікарям-інтернам та курсантам відпрацьовувати практичні навички, алгоритм надання допомоги при ситуаціях, найбільше наближених до реальних в акушерстві та гінекології [4].

Викладачі кафедри акушерства та гінекології факультету післядипломної освіти зацікавилися цим методом навчання і протягом 2016-2017 рр. відвідали акушерські симуляційні центри в містах Вінниці та Івано-Франківську, які були сформовані раніше.

Викладачі отримали з обох симуляційних центрів сертифікати про проходження тренінгів та оволодіння принципами роботи в симуляційному центрі.

Ми запропонували імітаційну методику навчання, яка створена на основі методик рольової гри і стандартизованої пацієнтки. У симуляційному центрі є окремі облаштовані кімнати для вивчення окремих дисциплін: акушерства і гінекології, анестезіології і реанімації, педіатрії, які облаштовані відповідними тренажерами, манекенами. 3 високотехнологічних тренажерів є: інтерактивний симулятор пологів, інтерактивні манекени новонародженого, гінекологічного та акушерського огляду.

У симуляційному центрі для лікарів-інтернів та курсантів створюються ситуаційні задачі з тем термінальних станів в акушерстві та гінекології. Для вирішення ситуаційної задачі створюється бригада лікарів-інтернів або курсантів із 4-5 чоловік, яка симулює чергову бригаду лікарів, що надає допомогу вагітній жінці в родопомічному закладі. Отже, інтерни поділяються на групи, які імітують бригаду чергового персоналу: «пацієнтка», черговий акушер-гінеколог, відповідальний черговий акушер-гінеколог, ургентний акушер-гінеколог, лікар-анестезіолог, лікар-трансфузіолог, акушерка родзалу, акушерка приймального відділення, анестезистка, операційна сестра, санітарка родзалу, лаборант. «Пацієнтка» отримує завдання - зіграти роль вагітної з гестозом. Розроблено сценарій, який змінюється залежно від дій персоналу. Викладач звертає увагу на вміння лікаря правильно зібрати анамнез, призначити необхідні обстеження, призначити лікування. «Пацієнтка» повинна чітко відповідати на запитання лікаря, не видаючи зайвої інформації. I відповідно до даної акушерської ситуації працює бригада. Викладач оцінює дію лікарів-інтернів та правильність дій персоналу відповідно до клінічних настанов, оцінку їх дій, швидкість реакцій та правильність виконання призначень та маніпуляцій. Дії учасників ситуаційної задачі записуються в реальному часі. Оцінювання 
проводиться за чітко заданими критеріями. Викладач оцінює кожного з учасників гри. Отже, проведення симуляційних навчань - це безпечне та надійне освітнє середовище для навчання клінічних умінь. В дебрифінговій кімнаті викладач разом 3 інтернами проводить перегляд виконання завдань кожним учасником та аналізує правильність, етапність надання допомоги. Функціональні тренажери забезпечували моментальну та об'єктивну інформацію щодо правильності виконання ключових прийомів. Все це в комплексі дозволяло ефективно тренувати і закріплювати навички індивідуальної та спільної роботи. Одночасно аналізують не тільки навички надання медичної допомоги, але й комунікативні навички.

Отже, після завершення всіх дій ситуаційної задачі всі лікарі, які брали участь і які спостерігали збоку, збираються у залі та переглядають відео із наступним обговоренням кожного етапу та дії надання медичної допомоги. Викладач робить зауваження та висновки. Всі учасники проведення симуляційного завдання отримують справжні емоційні переживання та задоволення від пережитого.

Висновки та перспективи подальших досліджень. Таким чином, завданням сучасної освіти в підготовці майбутніх фахівців є використання як рутинних, так і іноваційних методологій навчання. Використовуючи значний досвід попередньої

\section{Список літератури}

1. Артьоменко В. В. Симуляційне навчання в медицині: міжнародний та вітчизняний досвід / В. В. Артьоменко // Одеський медичний журнал. - 2015. - № 6 (152). С. 67-74.

2. Ващенко В. Ю. Дистанционная форма обучення. История. Проблемы. Перспективы развития [Электронный ресурс] / В. Ю. Ващенко, В. А. Скляров, К. О. Козяков // Вісник Східноукраїнського національного університету імені В. Даля : електронне наукове фахове видання. 2009. - № 6E. - Режим доступу : http://www.nbuv.gov. ua/e-journals/vsunud/2009-6E/Index.htm.

3. Вороненко Ю. В. Дистанційне навчання в режимі on-line: нові можливості для професійного розвитку, нові перспективи / Ю. В. Вороненко // Український медичний часопис. - 2011. - № 3.

4. Дистанційне навчання - вимушений захід чи вимога часу (на прикладі Тернопільського національного медичного університету імені І. Я. Горбачевського МОЗ України)? / М. М. Корда, А. Г. Шульгай, А. І. Машталір, А. В. Чорномидз // Медична освіта. - 2021. № 2. - C. 35-40. викладацької роботи, кафедра активно працює над впровадженням дистаційного навчання. Завданням дистанційного навчання на післядипломному етапі освіти лікарів-інтернів та лікарів-курсантів акушерів-гінекологів є самостійна цілеспрямована робота з використанням сучасних IT, ефективність яких залежить від методологічно грамотно побудованого викладачем навчального процесу та інформаційно-комунікаційних можливостей закладу вищої освіти.

Активне використання симуляційного центру для формування «стійкого» алгоритму надання невідкладної допомоги при різних термінальних станах в акушерстві та гінекології у лікарів-інтернів та курсантів сприяє ефективному підвищенню рівня кваліфікації як на ментальному, так і на практичному рівнях.

Зважаючи на європейський вектор розвитку, майбутня система охорони здоров’я в Україні має бути узгоджена з європейськими принципами.

Перспективами щодо розвитку вищої медичної освіти України є постійне підвищення якості освіти, оновлення її змісту та форм організації навчально-виховного процесу, розвиток освіти як державно-суспільної системи; піднесення вищої освіти України до рівня вищої освіти розвинутих країн світу та інтеграції її у міжнародне науковоосвітнє співтовариство.

5. Кінаш Н. М. Напрямки реорганізації вищої медичної освіти в Україні / Н. М. Кінаш // Архів клінічної медицини. - 2015. - № 2. - С. 77-80.

6. Култаєва М. Д. Освітня євроінтеграція чи конституювання європейського освітнього простору? / М. Д. Култаєва // Педагогіка і психологія. - 2015. - № 4. - С. 23-29.

7. Лесневська К. В. Розвиток іншомовної комунікативної компетенції у контексті рекомендацій Ради Європи з мовної освіти [Електронний ресурс] / К. В. Лесневська // Наук. зап. Нац. ун-ту «Острозька академія». Серія «Філологічна». - 2016. - Вип. 62. - С. 196-198. - Режим доступу : http://nbuv.gov.ua/UJRN/Nznuoaf 20166272.

8. Леу С. Зв’язок професійної освіти і ринку праці: європейські перспективи / С. Леу // Проф.-техн. освіта. - 2017. - № 1. - С. 60-61.

9. Муравьев К. А. Симуляционное обучение в медицинском образовании - переломный момент / К. А. Муравьев, А. Б. Ходжаян, С. В. Рой // Фундаментальные исследования. - 2011. - № 10, ч. 3. - С. 534-537.

10. Некряч А. Реалізація освітніх стандартів ЮНЕСКО - запорука входження України в європей- 
ський цивілізаційний простір / А. Некряч // Вища школа. - 2016. - № 3. - С. 11-22.

11. Попова Л. Д. Перспективи використання симуляційних технологій на теоретичних кафедрах / Л. Д. Попова, О. А. Наконечна, С. О. Стеценко // Симуляційне навчання в системі підготовки медичних кадрів : матеріали L навч.-метод. конф., присвяченої 212-й річниці від дня заснування ХНМУ. - Х., 2016. - С. 134-136.

12. Проблеми та перспективи вищої медичної освіти у реалізації Національної стратегії реформування системи охорони здоров’я України / В. М. Мороз, Ю. Й. Гумін- ський, Л. В. Фоміна, Т. Л. Полеся // Проблеми та перспективи вищої медичної школи у розробці та реалізації національної стратегії побудови нової системи охорони здоров’я в Україні на період 2015-2025 рр. : тези доповідей. - 2015. - С. 1-6.

13. Про удосконалення післядипломної освіти лікарів : наказ МОЗ України від 10.12.2010 р. № 1088.

14. Танцюра Л. Д. Аудит оцінки лікарями дистанційної форми навчання на етапі післядипломної освіти / Л. Д. Танцюра, І. В. Кисельова, А. В. Біляєв // Медична освіта. - 2020. - № 4. - С. 100-104.

\section{References}

1. Artiomenko, V.V. (2015). Symuliatsiyne navchannia v medytsyni: mizhnarodnyi ta vitchyznianyi dosvid [Simulation in medical education: international and national experience]. Odeskyi medychnyi zhurnal - Odesa Medical Journal, 6, 152, 67-74 [in Ukrainian].

2. Vashchenko, V.Yu., Sklyarov, V.A., \& Kozyakov, K.O. (2009). Distantsionnaya forma obuchennya. Istoriya. Problemy. Perspektivy razvitiya [Distance learning form. History Problems. Prospects for development]. Visnyk Skhidnoukrayinskoho natsionalnoho universytetu imeni V. Dalya - Bulletin of V. Dal East-Ukrainian National University, 6E. Retrieved from: http://www.nbuv.gov.ua/ejournals/vsuvus/2009-6E/Index.htm [in Russian].

3. Voronenko, Yu.V. (2011). Dystantsiyne navchannya v rezhymi on-line: novi mozhlyvosti dlya profesiynoho rozvytku, novi perspektyvy [On-line distance learning: new opportunities for professional development, new perspectives]. Ukrayinskyy medychnyy chasopys Ukrainian Medical Journal, 3 [in Ukrainian].

4. Korda, M.M., Shulgai, A.G., Mashtalir, A.I., \& Chornomidz, A.V. (2021). Dystantsiyne navchannya vymushenyy zakhid chy vymoha chasu (na prykladi Ternopils'koho natsionalnoho medychnoho universytetu imeni I. YA. Horbachevskoho MOZ Ukrayiny)? [Distance learning - a forced measure or a requirement of time (on the example of I. Horbachevsky Ternopil National Medical University, Ministry of Health of Ukraine)?]. Medychna osvita - Medical Education, 2, 35-40 [in Ukrainian].

5. Kinash, N. (2015). Napryamky reorhanizatsiyi vyshchoyi medychnoyi osvity v Ukrayini [Directions of Reorganization of Higher Medical Education in Ukraine]. Arkhiv klinichnoyi medytsyny - Archive of Clinical Medicine, 2, 77-80 [in Ukrainian].

6. Kultaeva, M.D. (2015). Osvitnya yevrointehratsiya chy konstytuyuvannya yevropeyskoho osvitnioho prostoru? [Educational European integration or constitution of the European educational space?]. Pedahohika i psykholohiyaPedagogy and Psychology, 4, 23-29 [in Ukrainian].

7. Lesnevskaya, K.V. (2016). Rozvytok inshomovnoyi komunikatyvnoyi kompetentsiyi u konteksti rekomendatsiy Rady Yevropy z movnoyi osvity [Development of foreign language communicative competence in the context

of the recommendations of the Council of Europe on language education]. Nauk. zap. Nats. un-tu «Ostrozka akademiya». Seriya «Filolohichna»-Proceedings National Un-th "Ostroh Academy". Series "Philological”, 62, 196-198. Retrieved from: http://nbuv.gov.ua/UJRN/ Nznuoaf_2016_62_72 [in Ukrainian].

8. Leu, S. (2017). Zvyazok profesiynoyi osvity i rynku pratsi: yevropeyski perspektyvy [Communication of vocational education and the labor market: European perspectives]. Prof.-tekhn. osvita - Vocational and Technical Education, 1, 60-61 [in Ukrainian].

9. Muravev, K.A., Khodzhayan, A.B., \& Roy, S.V. (2011). Simulyatsionnoe obuchenie v meditsinskom obrazovanii - perelomnyy moment [Simulation training in medical education - a watershed moment]. Fundamentalnye issledovaniya - Fundamental Research, 10 (3), 534537 [in Russian].

10. Nekhryach, A. (2016). Realizatsiya osvitnikh standartiv YUNESKO - zaporuka vkhodzhennya Ukrayiny $\mathrm{v}$ yevropeyskyy tsyvilizatsiynyy prostir [Implementation of educational standards of UNESCO - a guarantee of Ukraines entry into the European civilization space]. Vyshcha shkolaHigher School, 3, 11-22 [in Ukrainian].

11. Popova, L.D., Nakonechna, O.A., \& Stetsenko, S.O. (2016). Perspektyvy vykorystannia symuliatsiynykh tekhnolohiy na teoretychnykh kafedrakh [Prospects for the use of simulation technologies in theoretical departments]. Symulyatsiine navchannia $v$ systemi pidhotovky medychnykh kadriv: materialy L navchalno-metodychnoi konferentsii, prysviachenoi 212-iy richnytsi vid dnia zasnuvannia KhNMU - Simulation training in education of medical personnel, materials of L educational conference dedicated to 212 anniversary of the founding KhNMU. Kharkiv [in Ukrainian].

12. Moroz, V.M., Guminsky, Yu.I., Fomina, L.V., \& Polesya, T.L. (2015). Problemy ta perspektyvy vyshchoyi medychnoyi osvity u realizatsiyi Natsionalnoyi stratehiyi reformuvannya systemy okhorony zdorovya Ukrayiny [Problems and prospects of higher medical education in the implementation of the National strategy of reforming the health care system of Ukraine]. Problemy ta perspektyvy vyshchoyi medychnoyi shkoly u rozrobtsi ta realizatsiyi 
natsionalnoyi stratehiyi pobudovy novoyi systemy okhorony zdorovya v Ukrayini na period 2015-2025: tezy dopovidey Problems and Prospects of the Higher Medical School in the Development and Implementation of the National Strategy for the Construction of a New Health Care System in Ukraine for the Period 2015-2025: Theses of Reports [in Ukrainian].

13. Nakaz MOZ Ukrayiny Pro udoskonalennya pislyadyplomnoyi osvity likariv vid 10.12.2010 r. № 1088 [Order of the Ministry of Health of Ukraine On the Improvement of Postgraduate Education of Physicians dated 10.12.2010 No. 1088] [in Ukrainian].

14. Tantsiura, L.D., Kyselova, I.V., \& Biliaiev, A.V. Audyt otsinky likaryamy dystantsiynoyi formy navchannya na etapi pislyadyplomnoyi osvity [Audit of evaluation of distance learning by doctors at the stage of postgraduate education]. Medychna osvita - Medical Education, 4, 100104 [in Ukrainian].

Електронна адреса для листування: appag_kaf@ukr.net 